\title{
Tænkepause og europæisk sikkerhedspolitik
}

\section{Niels Aadal Rasmussen}

EU har længe haft vanskeligt ved at gennemføre en sammenhængende Fælles Udenrigs- og Sikkerhedspolitik. Nu får Tyskland og Frankrig chancen for at rette skuden op inden 2009, hvor en ny Kommission og et nyt Europa-Parlament træder til. Men det kan kun ske, hvis EU's tænkepause benyttes til at finde en farbar vej i samklang med de europæiske borgeres ønsker

EU er grundlæggende splittet som politisk system: Der er ingen overordnet politisk ledelse, beslutninger tages ofte i enstemmighed, og selv når $\mathrm{EU}$ vælger at træffe beslutninger på grundlag af kvalificeret flertal, tages der særlige hensyn til de enkelte medlemslandes nationale interesser.

Denne institutionelle splittelse har modvirket bestræbelser på at styrke sammenhængen i EU's forhold udadtil. Dels har de enkelte medlemslande ofte forskellige nationale interesser, ligesom medlemslandene og EU's fælles institutioner, altså Kommissionen og Parlamentet som begge skal afbalancere med- lemslandenes regeringer i Rådet, ofte har meget forskellige ideer til, hvad der bedst tjener 'Unionens interesser'. Dels har funktionelle forskelle mellem de enkelte EU-politikker i stigende grad gjort det vanskeligt at samordne dem.

Derfor har EU længe haft vanskeligt ved at gennemføre en sammenhængende Fælles Udenrigs- og Sikkerhedspolitik herunder den Europæiske Sikkerheds- og Forsvarspolitik.

EU er som politisk system funktionelt splittet op i en række undersystemer, som hver for sig forfølger forskellige delmål på EU's dagsorden, organiseret i EU's tre søjler: 
(1) Fællesskabet, (2) Udenrigspolitikken og (3) Retslige og indre anliggender. Ligesom nationalstater har også EU forskellige interesser, som strider mod hinanden, og der kan gives adskillige eksempler på selvmodsigende udenrigs-initiativer.

Maastricht- og Amsterdam-traktaterne søgte at gøre op med de modstridende interesser ved at tilskynde Rådet og Kommissionen til at samarbejde om en højere grad af sammenhæng i EU's forhold udadtil. Udkastet til Forfatningstraktat indeholdt forslag til at styrke sammenhængen mellem forskellige politikker udadtil ved at skabe et fælles retsgrundlag. Søjlestrukturen skulle opløses, således at udenrigs-, sikkerheds- og forsvarspolitik såvel som retlige og indre anliggender samt ikke mindst handels- og udviklingspolitik skulle udformes i sammenhæng.

En sådan ophævelse skulle styrke såvel den institutionelle sammenhæng mellem Rådet og Kommissionen som sammenhængen på tværs mellem de forskellige politikker. Begge disse formål var afgørende vigtige for at opnå de ambitiøse mål, EU havde stillet sig med vedtagelsen i 2003 af den europæiske sikkerhedsstrategi, 'Et sikkert Europa i en bedre verden'.

\section{Sikkerhedsstrategien}

Den europæiske sikkerhedsstrategi peger på de afgørende internationa- le trusler og udfordringer, som de tegner sig efter 11 . september 2001 i form af terrorisme, spredning af masseødelæggelsesvåben, regionale konflikter, sammenbrudte stater og organiseret kriminalitet.

Svarene herpå forekommer at være en bred kombination med udgangspunkt i politisk og diplomatisk forebyggelse samt behandling i kompetente internationale organisationer, den såkaldte effektive multilateralisme. Dernæst må der bygges på indgreb under FN-pagten, altså med FN's Sikkerhedsråd i en afgørende rolle.

Traditionelt forsvar af staters territorier er ikke længere tilstrækkeligt, fordi forsvaret mod de nye trusler ofte må finde sted også uden for Europa. Sikkerhedsstrategien påpeger, at truslen om spredning af masseødelæggelsesvåben kan vokse sig uhåndterlig, ligesom terrorisme er tilbøjelig til at komme ud af kontrol, hvis der ikke gribes ind i tide. Indgrebene kan derfor ikke begrænses til militære modforanstaltninger, men må indbefatte efterretninger, retlige, politimæssige og andre midler, herunder også økonomiske forholdsregler eller sanktioner.

EU er enestående velplaceret til at spille en rolle over for de nye, mangesidige udfordringer med kombinationen af økonomisk samarbejde politisk og militært potentiale. Sikkerhed og udvikling bliver i stigende grad to sider af samme sag: God regeringsførelse er ikke længere blot 
et spørgsmål om at udvikle ansvarlige og effektive statslige strukturer i udviklingslandene. Det er også, og måske nok så meget, et spørgsmål om at bekæmpe terrorismens infrastruktur såsom hvidvaskning af penge og våbensmugling.

Ifølge Forfatningstraktaten skal ansvaret for den praktiske koordination af EU's forskellige politikker udadtil påhvile EU's fælles udenrigsminister.

Udenrigsministeren skal dels være formand for Rådet for Udenrigsanliggender (dvs. medlemslandenes udenrigsministre), dels være én af Kommissionens viceformænd, og dermed styrke sammenhængen mellem EU's forskellige eksterne politikker. Det er meningen, at udenrigsministeren skal varetage den fælles udenrigs-, sikkerheds-, og forsvarspolitik på vegne af medlemsstaterne med støtte i dels den europæiske sikkerhedsstrategi, dels en medarbejderstab, der skal bistå ministeren i det konkrete politiske arbejde.

\section{Fælles udenrigstjeneste}

Den 'Fælles Udenrigstjeneste', der er en del af Forfatningstraktaten, hviler fortsat på yderst usikkert grundlag. Den skulle i princippet først falde på plads efter Forfatningstraktatens ikrafttræden, men opbygningen har allerede været på bordet i form af et fælles udspil fra den, der i givet fald skulle være EU's kommende udenrigsminister, generalsekretær Javier Solana, og Kommissionens nye formand, Manuel Barosso.

Den Fælles Udenrigstjenestes opgaver kendes endnu ikke nærmere, men de vil givetvis omfatte den informationsindhentning, som er nødvendig for at gennemføre den Fælles Udenrigs- og Sikkerhedspolitik og samordne EU's optræden udadtil på grundlag af de eksisterende eksterne politikker. Det vil sandsynligvis betyde, at bearbejdningen af i hvert fald visse informationer kommer til at ske i en slags udenrigsministerium.

Umiddelbart er der meget der tyder på, at den institutionelle opbygning af den Fælles Udenrigstjeneste fortsætter, uanset hvad der måtte blive Forfatningstraktatens videre skæbne. Behovet for en bedre samordning er simpelthen så indlysende og presserende, at der kan opnås politisk enighed om at videreudvikle samarbejdet også uden en Forfatningstraktat. Den løsning stats- og regeringscheferne skal finde frem til på det organisatoriske plan kommer til at ligge mellem et minimalt og et maksimalt yderpunkt.

Den minimale udenrigstjeneste ville bestå af nogle få enheder i Rådssekretariatet og Kommissionen samt EU's nuværende 128 repræsentationer i andre lande og organisationer. Ulempen ved en sådan konstruktion vil formentlig være, at udenrigspolitiske generalister vil vise sig dårligt 
egnede til at løse specifikke opgaver vedrørende udviklingspolitik og humanitær bistand.

Den maksimale udenrigstjeneste ville foruden EU's repræsentationer $i$ andre lande og organisationer bestå af samtlige enheder i Rådssekretariatet med opgaver udadtil, altså også landbrug og fiskeri, industri, energi og miljø, retlige og indre anliggender osv., foruden tilsvarende dele af Kommissionen samt Generaldirektoraterne for Udviklingsbistand, Humanitær hjælp og Udvidelse. Ulempen ved en maksimal løsning er, at den fra starten vil føre til interne magtkampe og på længere sigt til formidable koordinationsproblemer samt reaktioner fra administrationerne i især de store medlemsstater.

Den europæiske opinion støtter ifølge meningsmålinger i vidt omfang Forfatningstraktatens ambition om en styrkelse af EU's udenrigs- og sikkerhedspolitik, herunder ESDP. Det kan derfor ikke overraske, at den udenrigspolitiske koordinator Solana tager til orde for en global rolle for EU, som han siger har en samlet strategi for både det vestlige Balkan, Mellemøsten, Afrika og den østlige del af Europa.

Solana peger på fire områder, der må forbedres: (1) forbedrede militære evner ved forøgede forskningsbevillinger til især dækning af mangler som fx strategisk løftekapacitet, især fly og skibe, (2) forbedrede ledelsesstrukturer, herunder også $\mathrm{i}$ forhold til naturkatastrofer som tsunamien, (3) forøgede bevillinger til den fælles udenrigspolitik, herunder til civile operationer samt (4) forberedelse af den formentlig hidtil største EU-operation, nemlig i Kosovo med forbedret koordination af alle EU-operationer på det vestlige Balkan, herunder kampen mod organiseret kriminalitet.

\section{Tænkepausen 2005-2007}

Tænkepausen blandt EU's politiske ledere og Kommissionen peger i stigende grad i retning af et 'projekternes Europa' til gavn for Unionens borgere, med konkret udbytte for vælgerne.

Traktatprojektets skibbrud har givet anledning til navnlig to typer svar på det dilemma, som består i, at yderligere praktisk udbytte vanskeliggøres under de eksisterende traktater: Et maksimalistisk svar, som vil se bort fra de franske og nederlandske afvisninger af Forfatningstraktaten, og et udbyggende eller organisk svar, som ønsker at begrave Forfatningstraktaten og erstatte den med en 'mini-traktat', der skulle udbygge de eksisterende traktater, men ikke kaldes en Forfatning.

Den maksimalistiske løsning bygger på erfaringerne fra det danske nej til Maastricht-traktaten og Edinburgh-protokollen, som indførte de fire danske EU-forbehold vedrørende den fælles mønt, unionsborgerskab, politisamarbejde og forsvar, 
samt det irske nej til Nice-traktaten, således at de franske og nederlandske vælgere på ny skulle stemme om Forfatningstraktaten. En sådan løsning ville formentlig forudsætte tilføjelse af et Socialt Charter for at gøre løsningen mere acceptabel for navnlig de franske vælgere.

Den organiske løsning indebærer en mini-traktat omfattende de formentlig mindre kontroversielle elementer i Forfatningstraktaten såsom posterne som Kommissions-formand og udenrigsminister (formentlig med en Fælles Udenrigstjeneste), begrænsning af antallet af kommissærer som foreskrevet i Nice-traktaten, og reglerne om dobbelt flertal.

En sådan løsning ville ikke nødvendigvis medføre vanskelige folkeafstemninger, hvis den kunne udformes som en protokol til den næste udvidelse af Unionen. En sådan strømlining af institutionerne ville bevirke større gennemsigtighed i beslutningsprocessen og dermed styrke den demokratiske indflydelse i EU.

Den politiske proces frem mod en løsning på forfatningskrisen kan tænkes at ske efter forskellige scenarier:

Scenario 1 ville være, at ratifikationsprocessen genoptages med fare for fornyet afvisning i Frankrig og Nederlandene, men også med risiko for afvisning i såvel nye som gamle medlemslande.

Scenario 2 ville være en mini-traktat med bevarelse af institutionelle ændringer til fordel for EU's handlekraft udadtil uden folkeafstemninger, men med risiko for at blive brudt op i hårdt tilkæmpede kompromiser.

Scenario 3 ville være bibeholdelse af eksisterende traktater dog tilpasset væsentlige ændringer til fordel for handlekraft udadtil sås afstemningsprocedurer og ophævelse af søjlestrukturen. Den Europæiske Sikkerheds- og Forsvarspolitik kunne styrkes i kraft af flertalsafstemninger omkring indsættelse af EU's kampgrupper og omkring Forsvarsagenturet. Her foreligger risiko for omgåelse af de demokratiske procedurer.

Og scenario 4 ville være udarbejdelse og godkendelse af en ny forfatning med mulighed for forstærket samarbejde inden for Eurogruppen i stedet for Forfatningstraktaten. Det ville være tidskrævende med 27 medlemsstater, og kunne samtidig føre til udsættelse af en senere EU-udvidelse.

\section{Vælgerapati}

Forfatningstraktatens forkastelse i Frankrig og Nederlandene i sommeren 2005 retter imidlertid opmærksomheden mod de forudgående valg til Europa-Parlamentet i 2004, som gav den laveste valgdeltagelse nogen sinde, hvilket ud fra et demokratisk synspunkt var langt mere bekymrende end de to folkeafstemninger. 
Vælgerne i de to lande havde dermed allerede umiddelbart efter EU's udvidelse udtrykt deres uro over optagelsen af de nye central- og østeuropæiske lande, som på deres side viste valget til Europa-parlamentet påfaldende ringe interesse.

Den mest nærliggende forklaring på denne apati fra vælgernes side synes at være manglende opslutning til det europæiske prestigeprojekt, som er blevet drevet af de europæiske økonomiske eliter med en vis støtte fra politiske og juridiske eliter, og som er kommet til udtryk i reformer af økonomi og arbejde med sigte på højere levestandard og mere forbrug.

I en tid hvor frygten for global opvarmning, forringelse af miljøet, illegal indvandring, menneskesmugling og grænseoverskridende organiseret kriminalitet står højt på borgernes dagsorden, ønsker de at støtte en europæisk proces, som bidrager til deres sikkerhed og fred, sociale rettigheder, tryghed og frihed.

Globaliseringen med udlicitering og udflytning af arbejdspladser har tilsyneladende ført til stagnation i flere europæiske økonomier og bekymring for arbejdsløshed, manglende social beskyttelse og økonomisk stilstand. Til gengæld viser meningsmålinger påfaldende høje og stigende forventninger til ESDP, og EU's borgere synes at forvente civile indsatser til fremme af demokrati i andre lande.

Det er derfor ikke overraskende, at europæerne generelt synes at foretrække civile frem for militære optioner med valgovervågning højt på listen og indsatser, der bygger på legitime og omkostningsbevidste midler. Den europæiske sikkerhedsstrategi 'Et sikkert Europa i en bedre verden', har tilsyneladende opfanget denne tendens, og ESDP-indsatserne i henholdsvis Georgien og Aceh er nylige eksempler på europæiske anstrengelser imod risikoen for sammenbrudte stater og potentiel terrorisme, regionale konflikter og organiseret kriminalitet.

\section{Projekternes Europa}

Den Fælles Udenrigs- og Sikkerhedspolitiks væsentligste svagheder er funktionel opsplitning og institutionel opdeling.

Forfatningstraktaten søgte at skabe et fælles retsgrundlag for at styrke institutionel sammenhæng og sammenhæng på tværs af de forskellige politikker. Set på baggrund ikke mindst af EU's udvidelse mod øst og sydøst er der grund til at tro, at fokus snarere bliver regionalt end globalt.

Forfatningsdebatten peger endvidere i retning af et 'projekternes Europa' med vægt på konkrete resultater, og den institutionelle mulighed som bedst synes at afspejle de politiske prioriteter, er en fortsat fornyelse af ESDP og dens operative muligheder. Det kan ske inden for de eksisterende traktater, tilpasset de vig- 
tigste institutionelle ændringer som afstemningssystemet i Rådet og fordelingen af pladser i institutionerne, men samtidig med opløsning af søjlestrukturen angående udenrigs- og sikkerhedspolitik samt retlige og indre anliggender.

EU har besluttet at forlænge tænkepausen fra 2005 ind i 2007, hvor Tyskland overtager Formandskabet og skal forsøge at drive integrationsprocessen videre. Denne timing svarer til vigtige politiske begivenheder i 2007 , navnlig præsidentvalget i Frankrig i maj-juni. Desuden peger den frem mod det franske Formandskab i andet halvår af 2008 og nyvalg til såvel Kommissionen som EuropaParlamentet i 2009.
Inden da ventes yderligere Bulgarien og Rumænien at blive medlemmer af EU, mens Kroatien venter i kulissen.

Artiklen bygger på en mere omfattende engelsksproget rapport fra DIIS om "EU Global Power? - Reflections on the European Security and Defence Policy after the failure of the 2004 Draft Constitutional Treaty", der indgår i DIIS' Forsvarsog Sikkerhedspolitiske Studier, som foretages på en bevilling fra Forsvarsministeriet.

Niels Aadal Rasmussen er ministerråd og midlertidig forsker ved DIIS 